\title{
Tipe-Tipe Kualitas Perkawinan Orang Yogyakarta
}

\author{
Siti Rohmah Nurhayati \\ Prodi Psikologi, Fakultas Ilmu Pendidikan, Universitas Negeri Yogyakarta, Indonesia \\ e-mail: siti_rohmah@uny.ac.id
}

\begin{abstract}
This study aims to explore the types of marital quality. A survey was distributed to 316 participants with the characteristics of having been married for at least five years and identified themselves as people of Yogyakarta, which were obtained purposively. The instrument used marital quality scale which was analyzed quantitatively using cluster analysis. Grouping using cluster analysis was based on indicators of marital quality, namely connectivity, passion, complementarity, mutual respect, mutual acceptance, sharing roles, carrying out the roles with responsibility, harmony, and happiness. The results of the analysis showed that there were three types of marital quality that is happy, functional, and survival type. The happy type is the best quality type that scores above the average population score for all indicators. The second, functional type, has a score below the first type, with variations for each indicator. The third type is the type with the lowest score compared to the other two types.
\end{abstract}

Keywords: marital quality, marriage, typology

\begin{abstract}
Abstrak
Penelitian ini bertujuan untuk menyusun dan mendeskripsikan tipe-tipe kualitas perkawinan. Metode penelitian ini adalah survei, dengan melibatkan 316 orang subjek dengan karakteristik telah menikah minimal lima tahun dan mengidentifikasi dirinya sebagai orang Yogyakarta, yang diperoleh secara purposif. Alat ukur menggunakan skala kualitas perkawinan yang selanjutnya dianalisis secara kuantitatif menggunakan analisis klaster. Pengelompokan menggunakan analisis klaster dilakukan berdasarkan indikator kualitas perkawinan yaitu konektivitas, gairah, saling melengkapi, saling menghargai, saling menerima, berbagi peran, menjalankan peran dengan tanggung jawab, harmonis, dan bahagia. Hasil analisis menunjukkan ada tiga tipe kualitas perkawinan, yaitu tipe bahagia, tipe fungsional, dan tipe bertahan. Tipe bahagia merupakan tipe kualitas terbaik yang memiliki skor di atas rerata skor populasi untuk semua indikatornya. Tipe fungsional memiliki skor di bawah tipe pertama, dengan variasi untuk masing-masing indikatornya. Tipe ketiga merupakan tipe dengan kualitas perkawinan paling rendah dibandingkan kedua tipe yang lain.
\end{abstract}

Kata Kunci: kualitas perkawinan, perkawinan, tipologi

\section{Pendahuluan}

Kualitas perkawinan mendapatkan perhatian dari banyak peneliti, bahkan mendominasi perhatian dalam studi perkawinan (Fowers \& Owenz, 2010), karena pengaruhnya yang penting terhadap hubungan suami istri serta kehidupan seseorang secara keseluruhan. Sebagai contoh, kualitas perkawinan secara konsisten berhubungan positif dengan kesejahteraan individu (Carr dkk., 2014, Chang, 2016), derajat kesehatan (Messina dkk., 2018), serta berhubungan negatif dengan gangguan tidur (Troxel dkk., 2017), stres, kesepian, dan depresi (Kim, 2012; Stokes, 2017; Goldfarb \& Trudel, 2019; Marini dkk, 2020).

Kualitas perkawinan didefinisikan secara beragam. Namun demikian, penelitian Nurhayati (2017) yang dilakukan pada orang Yogyakarta menemukan bahwa kualitas perkawinan merupakan tingkat keunggulan perkawinan yang dapat dilihat dari relasi suami istri berupa adanya kedekatan dan kehangatan hubungan, respek, dan kerja sama, serta kesejahteraan 
yang dirasakan oleh suami istri berupa kesejahteraan sosial dan kesejahteraan psikologis. Temuan konseptual tersebut merupakan kemajuan yang cukup berarti dalam studi kualitas perkawinan di Indonesia khususnya di Yogyakarta, karena penelitian tersebut dilakukan secara indigenous berdasarkan pengalaman khusus masyarakat lokal. Konsep keluarga bahagia manapun tidak berdiri di atas lahan kosong, tetapi merupakan subsistem dari sistem kemasyarakatan yang ada (Mubarok, 2012), dan seharusnya kualitas perkawinan tidak dipandang sebagai proses modernisasi yang menyebar kemana-mana (Nuckolls \& Krishnayya, 2010). Meskipun demikian, temuan Nurhayati (2017) tersebut belum cukup menggambarkan klasifikasi kualitas perkawinan yang ada.

Klasifikasi dapat dilakukan melalui upaya penyusunan kategorisasi, klasifikasi, atau tipologi. Collier dkk. (2012) menyatakan bahwa tipologi memiliki kontribusi yang sangat penting dalam tugas-tugas analisis: membentuk dan memperbaiki konsep, menggambarkan dimensi, membuat kategori-kategori untuk klasifikasi dan pengukuran, serta mengelompokkan kasus. Bergman (dalam Mandara \& Murray, 2002) menyatakan bahwa logika dasar dari pendekatan tipologi adalah bahwa tipe-tipe memiliki informasi yang lebih banyak daripada variabel-variabel yang digunakan untuk membentuknya. Hal tersebut disebabkan tipe-tipe diasumsikan sebagai gestalt yang efeknya sama sekali tidak dapat diprediksi dari agregasi tunggal (misalnya korelasi rata-rata) informasi tentang anggota kelompok, atau dapat dikatakan bahwa keseluruhan lebih dari jumlah bagianbagiannya (Anderson \& Sedikides, 1991; Mandara \& Murray, 2002).

Tipologi memberikan alat konseptual yang baik untuk deskripsi pengamatan, dan karena tipologi mengandung konsep yang dibutuhkan bagi pengembangan teori, maka tipologi dipandang sebagai proses mendasar dari setiap ilmu (Aldenderfer \&
Bashfield, dalam Lavee \& Olson, 1993). Oleh karena itu pengembangan tipologi dilakukan di berbagai bidang, misalnya bidang media (Arora, 2012), perilaku remaja (Kim dkk., 2010), pariwisata (Kim \& Ritchie, 2012), bisnis teknologi informasi (Mills \& Pawson, 2012), perilaku menolong (Stidham dkk., 2012), hubungan industrial (Bechter dkk., 2012), pengangguran (van der Vaart dkk., 2017), kepribadian (Tolea dkk., 2012), dan warning behavior (Meloy dkk., 2012).

Olson (dalam Lavee \& Olson, 1993) menyatakan bahwa di bidang keluarga, perkawinan dan keluarga dapat diklasifikasikan secara heuristik dan empiris. Jika model heuristik dimulai dari dasar konseptual untuk mengklasifikasikan perkawinan atau keluarga pada tipe-tipe yang bermakna secara teoretis dan klinis, maka klasifikasi empiris dimulai dengan serangkaian pengamatan serta mengurangi jarak dan variasi pola-pola hubungan menjadi sejumlah kecil tipe.

Olson dan Fowers (1993) menegaskan bahwa klasifikasi perkawinan yang berdasar secara baik memiliki kegunaan yang sangat besar. Pengembangan kategori atau tipologi yang reliabel merupakan salah satu cara untuk menjembatani kesenjangan antara teori, penelitian, dan praktik. Tipologi empiris dapat menyediakan petunjuk pada teori berkaitan dengan kombinasi dari variabel seperti apa yang paling relevan di dalam memahami perbedaan-perbedaan tentang bagaimana perkawinan dibentuk. Kelebihan lain dari penelitian tipologi adalah bahwa tipologi menggunakan pendekatan multivariat, yang secara lebih tepat dapat menangkap kompleksitas hubungan pasangan suami istri daripada penelitian yang memusatkan pada satu atau dua dimensi dari perkawinan. Selain itu penelitian tipologi juga dapat membantu para praktisi dalam mengorganisasikan pola-pola perbedaan pasangan yang ditemui. 
Beberapa upaya telah dilakukan oleh para ahli untuk membuat klasifikasi atau pengelompokan kualitas perkawinan dengan dasar pengklasifikasian yang berbeda-beda. Beberapa penelitian di bawah ini adalah tipologi empiris kualitas perkawinan yang didasarkan dari penelitian lapangan atas beberapa variabel. Cohen, dkk. (2010) dengan menggunakan analisis klaster menemukan tiga tipologi kualitas perkawinan yang bertahan lama di Israel, yaitu vitalized, satisfactory, dan conflictual marriages. Liu dan Upenieks (2020) membangun tipologi jenis perkawinan yang menghubungkan antara kualitas perkawinan positif dan negatif dengan kesehatan. Terdapat empat jenis perkawinan dalam penelitian ini, yaitu supportive, aversive, ambivalent, dan indifferent. Mereka menemukan bahwa laki-laki dan perempuan yang berada dalam perkawinan tipe aversive melaporkan kesejahteraan dan kesehatan yang rendah.

Dush dan Taylor (2012) mengidentifikasi kualitas perkawinan yang paling tinggi dan paling rendah dengan mengombinasikan perjalanan kebahagiaan perkawinan dengan konflik perkawinan. Mereka menemukan lima tipe perkawinan, yaitu validator marriages, merupakan perkawinan dengan kebahagiaan tingkat tinggi namun konflik tingkat sedang dan kebahagiaan sedang dengan konflik juga sedang; volatile marriages, yaitu perkawinan yang berada pada tingkat kebahagiaan tinggi namun tingkat konfliknya juga tinggi serta perkawinan yang tingkat kebahagiaannya sedang namun konfliknya tinggi; avoider marriages adalah perkawinan yang tingkat kebahagiaannya tinggi dengan konflik rendah serta perkawinan dengan tingkat kebahagiaan sedang dan konflik rendah; hostile-engaged marriages adalah pasangan yang menunjukkan kebahagiaan rendah dengan konflik yang tinggi serta mereka yang menunjukkan tingkat kebahagiaan rendah dengan konflik sedang; dan hostiledetached marriages, yaitu perkawinan yang menunjukkan tingkat kebahagiaan yang rendah dengan konflik yang rendah pula.

Beberapa penelitian di atas menunjukkan bervariasinya tipe-tipe perkawinan, tergantung pada dimensi kualitas perkawinan yang digunakan sebagai parameter maupun konteks penelitian tersebut dilakukan. Sejauh pengetahuan penulis belum ada upaya penyusunan kategori atau tipe-tipe kualitas perkawinan yang teruji dalam konteks Indonesia, khususnya pada orang Yogyakarta. Nurhayati (2017) dalam penelitiannya terhadap orang Yogyakarta menemukan aspek-aspek kualitas perkawinan, yang meliputi: 1) kedekatan dan kehangatan hubungan yang ditandai dengan adanya konektivitas, saling percaya, gairah, dan saling melengkapi; 2) respek yang ditandai dengan saling menerima, saling mendukung, dan saling menghargai antara suami istri; 3) kerja sama yang muncul dalam bentuk pembagian peran dan memecahkan masalah secara bersamasama; dan 4) kesejahteraan berupa rasa tenteram atau bahagia, serta hubungan yang harmonis dengan pasangan. Aspek-aspek tersebut tentunya akan membentuk pola khusus tipologi kualitas perkawinan pada orang Yogyakarta. Berdasarkan hal itu, penelitian ini bertujuan untuk menyusun dan mendeskripsikan kategori atau tipe-tipe kualitas perkawinan secara empiris.

\section{Metode Penelitian}

Penelitian ini menggunakan desain penelitian kuantitatif. Penelitian dilaksanakan di Daerah Istimewa Yogyakarta. Subjek penelitian dipilih secara purposive, yaitu mereka yang mengidentifikasi dirinya sebagai orang Yogyakarta, berstatus menikah dengan lama pernikahan minimal 5 tahun, serta tinggal di Daerah Istimewa Yogyakarta. Sejumlah 316 orang berpartisipasi dalam penelitian ini, dan sebanyak 225 orang atau $71.4 \%$ merupakan orang-orang yang tinggal di Yogyakarta sejak lahir. Sisanya 
telah tinggal di wilayah Daerah Istimewa Yogyakarta antara 5 sampai 30 tahun.

Data penelitian dikumpulkan menggunakan skala kualitas perkawinan yang disusun Nurhayati (2017), terdiri dari dua dimensi. Dimensi pertama adalah dimensi relasi yang mengukur konektivitas (contoh item: "Saya dan pasangan biasa bertukar cerita tentang pengalaman masingmasing"), gairah (contoh item: "Saya dan pasangan menikmati saat bermesraan"), saling melengkapi (contoh item: "Saya dan pasangan menyempurnakan satu sama lain"), saling menghargai (contoh item: "Sebelum membuat keputusan penting, saya dan pasangan saling minta pendapat"), saling menerima (contoh item: "Saya dan pasangan tidak saling mengungkit kesalahan"), berbagi peran (contoh item: "Saya dan pasangan berbagi peran dalam mengurus rumah tangga"), dan tanggung jawab dalam menjalankan peran (contoh item: "Meskipun repot, saya dan pasangan berusaha menjalankan kewajiban masingmasing"). Sementara itu dimensi kedua adalah dimensi kesejahteraan yang mengukur keharmonisan (contoh item: "Jarang terjadi perselisihan diantara saya dan pasangan") dan kebahagiaan (contoh item: "Saya merasa senang hidup bersama pasangan saya").

Skala ini telah diujicobakan kepada 256 orang Yogyakarta. Berdasarkan hasil analisis, daya beda item-item pada dimensi relasi bergerak antara .228 sampai dengan .635 dengan rata-rata sebesar .465. Adapun pada dimensi kesejahteraan bergerak antara .475 sampai .744 dengan rata-rata .657. Skala ini memiliki validitas isi yang baik, dengan nilai Aiken's V bergerak antara .82 sampai dengan .97 dengan rata-rata untuk seluruh item sebesar .91. Validitas konvergen skala ini baik, dilihat dari nilai Average Varians Extracted (AVE) yang menunjukkan nilai .612 untuk konstruk relasi, dan .671 untuk konstruk kesejahteraan. Reliabilitas konstruk memenuhi standar, yaitu sebesar .824 untuk konstruk relasi, dan .802 untuk konstruk kesejahteraan.
Adapun reliabilitas skala secara keseluruhan dengan menggunakan penghitungan Cronbach's Alpha menunjukkan nilai sebesar .903 .

Data penelitian dianalisis dengan analisis klaster. Dalam penelitian ini, subjek penelitian dikelompokkan berdasarkan indikator kualitas perkawinan yang telah ditemukan sebelumnya oleh Nurhayati (2017) dalam sebuah penelitian yang dilakukan pada orang Yogyakarta, meliputi konektivitas, gairah, saling melengkapi, saling menghargai, saling menerima, berbagi peran, menjalankan peran dengan tanggung jawab, keharmonisan, dan kebahagiaan. Pengelompokan dilakukan dalam dua tahap. Pertama, analisis klaster dilakukan secara hierarkis untuk mencari jumlah klaster dan kesamaan-kesamaan struktur. Selanjutnya dilakukan analisis klaster $k$-means untuk mengklasifikasikan subjek berdasarkan hasil pada tahap pertama. Pada analisis ini, peneliti memutuskan skor menjadi standar dengan menggunakan $z$-score karena skor asli yang dimiliki masing-masing variabel tidak setara.

\section{Hasil Penelitian dan Pembahasan}

\section{Karakteristik Subjek}

Hasil analisis karakteristik demografi pasangan suami istri dalam penelitian ini menunjukkan rentang usia antara 21 tahun sampai 64 tahun, dengan persentase terbesar $(39.2 \%)$ berada pada rentang usia 31-40 tahun, dan 32.3\% berusia antara 4150 tahun. Pada usia perkawinan, persentase terbesar berada pada 5-10 tahun (39.2\%) serta 11-20 tahun (39.2\%), adapun sisanya telah menikah lebih dari 20 tahun. Mayoritas subjek memiliki dua anak $(45.3 \%)$ dan satu anak (28.5\%). Ditinjau dari tingkat pendidikan, sebanyak $36.7 \%$ merupakan lulusan SMU dan $33.5 \%$ merupakan sarjana, selebihnya merupakan lulusan SD, SMP, dan pascasarjana. 
Tabel 1

Karakteristik Demografi Subjek

\begin{tabular}{|c|c|c|}
\hline Demografi & Jumlah & $(\%)$ \\
\hline \multicolumn{3}{|l|}{ Usia } \\
\hline$\leq 30$ tahun & 46 & 14.5 \\
\hline $31-40$ tahun & 124 & 39.2 \\
\hline $41-50$ tahun & 102 & 32.3 \\
\hline $51-60$ tahun & 40 & 12.7 \\
\hline$\geq 61$ tahun & 4 & 1.3 \\
\hline Total & 316 & 100 \\
\hline \multicolumn{3}{|l|}{ Tingkat Pendidikan } \\
\hline SD & 27 & 8.5 \\
\hline SMP & 53 & 16.8 \\
\hline SMU & 116 & 36.7 \\
\hline Sarjana & 106 & 33.5 \\
\hline Master & 13 & 4.1 \\
\hline Doktor & 1 & .3 \\
\hline Total & 316 & 100 \\
\hline \multicolumn{3}{|l|}{ Pekerjaan } \\
\hline Profesional atas & 2 & .6 \\
\hline Profesional & 77 & 24.4 \\
\hline Pegawai & 30 & 9.5 \\
\hline Tenaga kerja & 48 & 15.2 \\
\hline Tenaga kerja terampil & 27 & 8.5 \\
\hline Tenaker semi terampil & 19 & 6 \\
\hline Wirausaha & 47 & 14.9 \\
\hline Entertainer & 1 & .3 \\
\hline Tidak bekerja & 65 & 20.6 \\
\hline Total & 100 & 100 \\
\hline \multicolumn{3}{|l|}{ Usia Perkawinan } \\
\hline 5-10 tahun & 124 & 39.2 \\
\hline 11-20 tahun & 124 & 39.2 \\
\hline 21-30 tahun & 52 & 16.5 \\
\hline $31 \mathrm{ke}$ atas & 16 & 5.1 \\
\hline Total & 316 & 100 \\
\hline \multicolumn{3}{|l|}{ Jumlah anak } \\
\hline 0 & 16 & 5.1 \\
\hline 1 & 90 & 28.5 \\
\hline 2 & 143 & 45.3 \\
\hline 3 & 42 & 13.3 \\
\hline 4 & 19 & 6.0 \\
\hline 5 ke atas & 6 & 1.9 \\
\hline Total & 316 & 100 \\
\hline
\end{tabular}

Terkait pekerjaan, sebanyak $24.4 \%$ bekerja sebagai profesional seperti guru, perawat, atau pegawai bank, serta sebanyak 20.6\% menyatakan diri tidak bekerja, seperti ibu rumah tangga dan pensiunan. Data demografi subjek selengkapnya dapat dilihat pada tabel 1 .

\section{Tipe-tipe Kualitas Perkawinan}

Indikator kualitas perkawinan dalam penelitian ini mengikuti indikator yang telah ditemukan dalam penelitian sebelumnya (Nurhayati, 2017), yaitu konektivitas, gairah, saling melengkapi, saling menghargai, saling menerima, berbagi peran, tanggung jawab dalam menjalankan peran, keharmonisan, dan kebahagiaan. Hasil analisis klaster menggunakan indikator-indikator tersebut menemukan adanya 3 tipe kualitas perkawinan, yaitu tipe bahagia, tipe fungsional, dan tipe bertahan.

Untuk menguji perbedaan karakteristik ketiga tipe tersebut, peneliti menggunakan analisis varians (ANOVA). Tabel 2 menyajikan rerata, deviasi standar, nilai perbandingan, dan signifikansi. Sebagaimana terlihat pada tabel 2, pengelompokan pada setiap variabel menunjukkan adanya perbedaan untuk ketiga kelompok atau tipe kualitas perkawinan. Hal tersebut dapat dilihat dari nilai perbandingan untuk semua variabel dengan $\mathrm{p} .000$. Selanjutnya profil dari ketiga tipe kualitas perkawinan tersebut dapat dilihat pada gambar 1. Gambar 1 menunjukkan adanya profil yang berbeda dari masing-masing tipe kualitas perkawinan.

\section{Tipe Bahagia}

Tipe bahagia memiliki karakteristik sebagaimana tampak dalam garis paling atas pada gambar 1. Berdasarkan profilnya terlihat bahwa tipe ini memiliki skor yang lebih tinggi dari rata-rata populasinya untuk semua indikator. Artinya, pasangan suami istri dengan tipe ini menunjukkan konektivitas yang baik, ditunjukkan dengan adanya komunikasi, saling memahami, serta kebersamaan di antara keduanya. Selain itu mereka juga mempertahankan gairah yang ada, dengan saling mencintai dan melakukan aktivitas seksual. Pasangan suami istri dengan tipe ini juga saling melengkapi satu sama lain. Mereka saling menghargai, saling menerima kekurangan, 
Tabel 2

Rerata Indikator Masing-masing Tipe Kualitas Perkawinan

\begin{tabular}{|c|c|c|c|c|c|c|c|c|}
\hline \multirow[b]{3}{*}{ Variabel kualitas perkawinan } & \multicolumn{6}{|c|}{ Rerata tipe kualitas perkawinan } & \multirow[b]{3}{*}{$\mathrm{F}$} & \multirow[b]{3}{*}{$\mathrm{p}$} \\
\hline & \multicolumn{2}{|c|}{$\begin{array}{c}\text { Fungsional } \\
(\mathrm{N}: 88)\end{array}$} & \multicolumn{2}{|c|}{$\begin{array}{l}\text { Bahagia } \\
(\mathrm{N}: 202)\end{array}$} & \multicolumn{2}{|c|}{$\begin{array}{c}\text { Bertahan } \\
(\mathrm{N}: 26)\end{array}$} & & \\
\hline & $\mathrm{M}$ & SD & $\mathrm{M}$ & SD & $\mathrm{M}$ & SD & & \\
\hline Konektivitas & 9.74 & 1.53 & 11.48 & .78 & 8.35 & 2.18 & 122.211 & .000 \\
\hline Gairah & 8.34 & 0.84 & 8.9 & .40 & 6.12 & 1.59 & 180.847 & .000 \\
\hline Saling melengkapi & 4.99 & 1.14 & 5.88 & .44 & 3.88 & 1.14 & 101.537 & .000 \\
\hline Saling menghargai & 13.42 & 1.45 & 14.54 & .88 & 10.08 & 2.15 & 166.484 & .000 \\
\hline Saling menerima & 4.61 & 1.08 & 5.55 & .78 & 4.08 & .98 & 55.947 & .000 \\
\hline Berbagi peran & 10.13 & 1.63 & 11.03 & 1.53 & 7.85 & 1.54 & 51.718 & .000 \\
\hline Tanggung jawab menjalankan peran & 5.40 & .79 & 5.84 & .43 & 4.42 & 1.29 & 61.712 & .000 \\
\hline Harmonis & 6.55 & 1.39 & 8.16 & 1.11 & 6.19 & 1.55 & 69.434 & .000 \\
\hline Bahagia & 23.1 & 3.05 & 26.25 & 3.05 & 18.35 & 3.05 & 408.981 & .000 \\
\hline
\end{tabular}

Tipe-tipe Kualitas Perkawinan

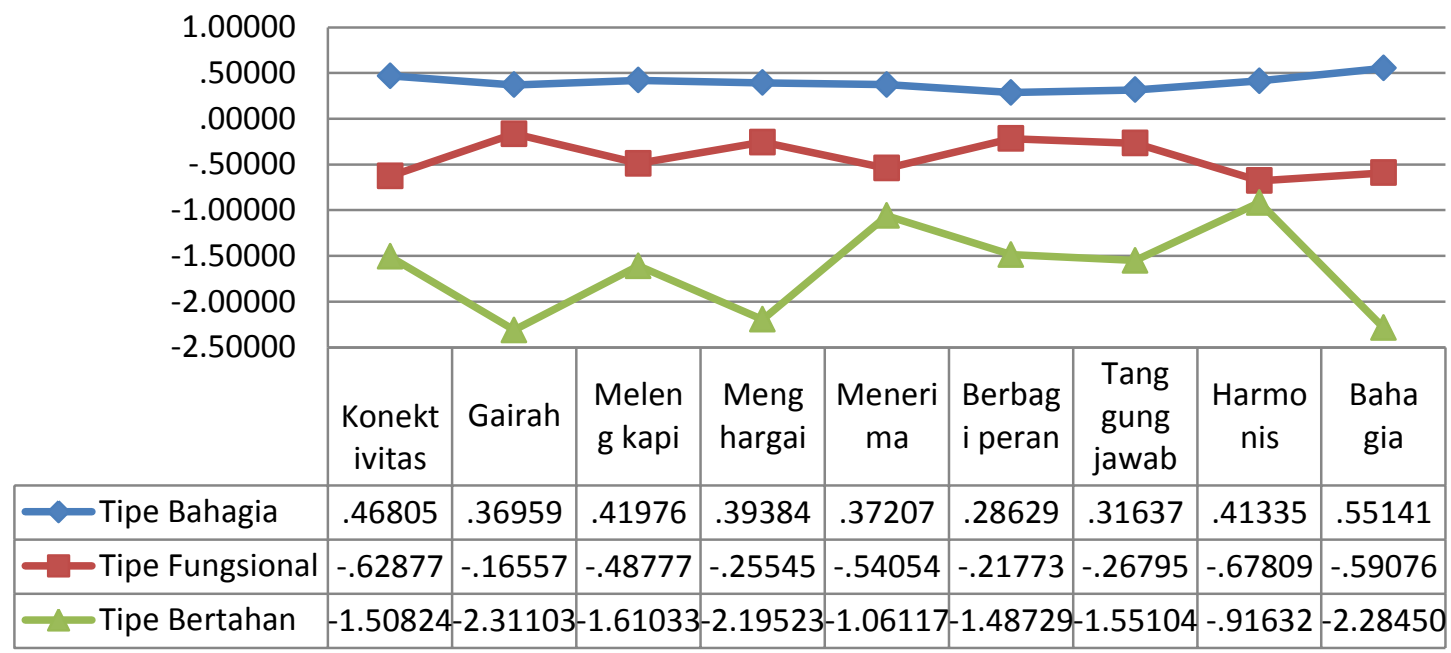

Gambar 1. Tipe kualitas perkawinan berdasarkan indikator kualitas perkawinan

berbagi peran dalam rumah tangga, dan masing-masing bertanggung jawab atas perannya. Pasangan ini juga menunjukkan hubungan yang harmonis serta merasa bahagia. Dilihat dari bentuk profilnya, tipe bahagia ini membentuk suatu garis yang landai. Artinya pasangan suami istri tipe ini memiliki skor yang relatif seimbang untuk semua indikatornya.

\section{Tipe Fungsional}

Tipe fungsional memiliki profil sebagaimana digambarkan oleh garis kedua pada gambar 1. Tipe ini memiliki skor kualitas perkawinan sedikit di bawah ratarata populasinya untuk semua indikatornya. Artinya secara umum pasangan tipe fungsional kurang optimal dalam menjalin relasi dengan pasangan serta memiliki kesejahteraan yang juga cenderung rendah. Pasangan ini mempertahankan gairah yang ada dengan saling mencintai dan memuaskan dalam aktivitas seksual, serta menunjukkan perilaku saling menghargai, berbagi peran dan tanggung jawab dalam menjalankan peran, namun dalam kadar yang cenderung rendah di bawah pasangan yang bahagia. Demikian juga dengan konektivitas, saling melengkapi, saling menerima, keharmonisan, dan kebahagiaan secara relatif sejajar berada di bawahnya. Berbeda dengan profil tipe bahagia, tipe fungsional memiliki garis yang sedikit bergelombang. Selain berbeda secara 
kualitas, garis tersebut juga menunjukkan dinamika yang unik untuk masing-masing tipe.

\section{Tipe Bertahan}

Pasangan suami istri dengan tipe bertahan memiliki rerata skor kualitas perkawinan di bawah rerata skor populasi untuk semua indikatornya. Dilihat dari profil garisnya sebagaimana tampak pada gambar 1, tipe bertahan menunjukkan satu garis zigzag atau tidak linear untuk indikator-indikatornya. Secara umum pasangan ini menunjukkan kualitas perkawinan yang rendah. Secara khusus, hal tersebut dapat dilihat dari rendahnya gairah dan sikap saling menghargai diantara pasangan. Komunikasi suami istri kurang terbuka, dengan pembagian peran serta tanggung jawab sekedarnya untuk mempertahankan rumah tangga. Sebagaimana tipe lainnya, pasangan ini relatif tidak suka bertengkar. Hal tersebut dapat diihat dari skor keharmonisan yang mendekati tipe fungsional. Namun demikian, pasangan tipe ini memiliki skor kebahagiaan yang jauh lebih rendah dibandingkan skor keharmonisan. Hal ini mengandung makna bahwa pasangan ini kurang berbahagia walaupun hubungannya rukun.

Hasil analisis data menunjukkan tidak ada perbedaan diantara ketiga tipe kualitas perkawinan dilihat dari aspek demografi, sebagaimana terlihat pada tabel 3 . Berdasarkan tabel 3 dapat diketahui bahwa untuk rerata usia perkawinan, tipe bahagia terlihat paling tinggi. Tipe bertahan terlihat memiliki rerata jumlah anak yang paling banyak. Untuk tingkat pendidikan, tipe bertahan juga memiliki rerata paling tinggi. Sementara itu rerata standar pengeluaran keluarga perbulan paling tinggi berada pada tipe bahagia. Meskipun ada perbedaan rerata pada aspek-aspek demografi, namun hal tersebut tidak signifikan. Oleh karena itu dapat dikatakan bahwa tidak ada perbedaan karakteristik demografi pada ketiga tipe kualitas perkawinan yang ditemukan.

Hasil penelitian ini menunjukkan terdapat tiga tipe kualitas perkawinan, yaitu tipe bahagia, tipe fungsional, dan tipe bertahan. Ketiga tipe kualitas perkawinan tersebut memperlihatkan adanya perbedaan kadar kualitas dari masing-masing indikatornya. Model tipologi sebagaimana yang ditemukan dalam penelitian ini relatif sama dengan tipologi kualitas perkawinan dari beberapa peneliti lain. Misalnya Cohen dkk. (2010) yang mengembangkan tipologi di Israel menemukan tiga tipe kualitas perkawinan yang bertahan lama di Israel, yaitu vitalized, satisfactory, dan conflictual marriage. Sebagaimana hasil penelitian ini, tipe-tipe kualitas perkawinan yang disusun oleh Cohen dkk. (2010) tersebut berbeda dalam hal kadar kualitas dari masingmasing indikatornya. Serupa dengan hal itu, Olson dan Fowers (1993) menemukan lima tipe kualitas perkawinan pada sampel orang Eropa-Amerika. Demikian juga Allen dan Olson (2001) yang menemukan lima macam kualitas perkawinan pada sampel orang-orang Afrika-Amerika.

Tabel 3

Rerata Aspek Demografi dan Uji Perbedaan Tiap Tipe

\begin{tabular}{|c|c|c|c|c|c|c|c|c|}
\hline \multirow[b]{3}{*}{ Variabel kualitas perkawinan } & \multicolumn{6}{|c|}{ Rerata tipe kualitas perkawinan } & \multirow[b]{3}{*}{$\mathrm{F}$} & \multirow[b]{3}{*}{$\mathrm{p}$} \\
\hline & \multicolumn{2}{|c|}{$\begin{array}{l}\text { Fungsional } \\
(\mathrm{N}: 88)\end{array}$} & \multicolumn{2}{|c|}{$\begin{array}{l}\text { Bahagia } \\
(\mathrm{N}: 202)\end{array}$} & \multicolumn{2}{|c|}{$\begin{array}{c}\text { Bertahan } \\
(\mathrm{N}: 26)\end{array}$} & & \\
\hline & $\mathrm{M}$ & SD & $\mathrm{M}$ & SD & $\mathrm{M}$ & $\mathrm{SD}$ & & \\
\hline Usia perkawinan & 1.84 & .856 & 1.90 & .846 & 1.77 & 1.032 & .353 & .703 \\
\hline Jumlah anak & 1.91 & 1.046 & 1.89 & 1.002 & 2.23 & .992 & 1.307 & .272 \\
\hline Tingkat pendidikan & 2.91 & .942 & 3.14 & 1.043 & 3.27 & 1.002 & 2.092 & .125 \\
\hline Standar pengeluaran keluarga & 2.31 & .748 & 2,58 & 1.109 & 2.38 & 1.098 & 2.416 & .091 \\
\hline Pekerjaan & 4.28 & 2.669 & 4.73 & 2.813 & 4.50 & 2.781 & .792 & .454 \\
\hline
\end{tabular}


Pada tipe bahagia, tampak bahwa skor pada indikator bahagia merupakan skor paling tinggi. Oleh karena itu tipe ini disebut sebagai tipe bahagia. Selain itu, berdasarkan penelitian Nurhayati (2017), kebahagiaan merupakan ujung atau output dari relasi yang berkualitas, sehingga kebahagiaan dapat menjadi pertanda adanya relasi suami istri yang baik. Tipe ini hampir sama dengan tipe vitalized dalam penelitian Allen dan Olson (2001) yang menunjukkan tipe perkawinan dengan skor baik pada hampir semua kriteria kualitas perkawinan pada pasangan Afrika Amerika, serta penelitian Cohen dkk. (2010) di Israel.

Skor yang tinggi untuk semua indikator pada tipe bahagia ini menggambarkan sebuah hubungan suami istri yang sehat, fungsional, harmonis, dan bahagia. Hubungan yang sehat ditunjukkan oleh adanya resiprositas atau timbal balik antara suami istri. Dalam perspektif teori interdependensi (Rusbult \& Van Lange, 2012), resiprositas menunjukkan adanya relasi yang bersifat mutual. Teori interdependensi menjelaskan adanya saling ketergantungan dalam relasi interpersonal. Ketika ketergantungan bersifat mutual, maka hal itu merupakan pertanda ada kesamaan dan kesetaraan kekuasaan antara suami istri. Pasangan dengan tipe bahagia menunjukkan saling timbal balik dalam komunikasi dan memahami, mencintai dan melakukan aktivitas seksual, melengkapi satu sama lain, menghargai dan menerima, berbagi peran dalam rumah tangga, serta bertanggung jawab. Oleh karena itu pasangan suami istri dengan tipe ini cenderung dapat mempertahankan hubungan yang harmonis dan merasakan kebahagiaan.

Tipe bahagia menunjukkan bahwa indikator-indikator kualitas perkawinan bekerja selaras satu sama lain. Kebahagiaan pasangan suami istri ada kaitannya dengan konektivitas, diantaranya adalah adanya komunikasi yang baik. Menurut AbreuAfonso dkk. (2021), kemampuan komunikasi berkaitan dengan kepuasan perkawinan. Sejalan dengan hal itu, komunikasi tentang seks secara terbuka dengan pasangan serta kepuasan dalam aktivitas seksual berkontribusi terhadap kepuasan hubungan secara umum (Montesi dkk., 2010) serta kebahagiaan (Heiman dkk., 2011). Para istri yang merasa puas dalam hubungan intim juga menunjukkan kepuasan dalam perkawinan (Herawati dkk., 2018).

Kebahagiaan juga dipengaruhi oleh penghargaan dan dukungan yang diterima dari pasangan. Orang-orang yang puas dan berbahagia di dalam perkawinannya melaporkan adanya kasih sayang dan dukungan dari pasangannya. Pada suami istri bekerja, tersedianya dukungan dari masing-masing pihak terhadap pasangannya dapat memperkecil konflik dalam perkawinan (Purohit \& Simmers, 2010). Sebaliknya, pembagian porsi tugas rumah tangga yang dianggap tidak adil berhubungan dengan rendahnya kepuasan terhadap hubungan dan kemungkinan terjadinya perceraian (Ruppanner dkk., 2018).

Tipe fungsional memiliki skor sedikit di bawah rata-rata populasinya untuk semua indikatornya. Menurut Reis dan Aron (2008), hasrat seksual sering dikaitkan dan pada hakekatnya berkaitan dengan cinta (passionate love). Oleh karena itu, aktivitas seksual bersama dengan adanya saling mencintai diantara pasangan suami istri dapat menunjukkan adanya gairah diantara mereka berdua. Mereka juga saling menghargai, berbagi peran dalam rumah tangga serta bertanggung jawab untuk menjalankannya. Perkawinan membawa konsekuensi pada pengelolaan rumah tangga yang harus dilakukan oleh sepasang suami istri. Beberapa penelitian menunjukkan bahwa pembagian peran antara suami istri di dalam tugas-tugas rumah tangga berhubungan dengan kualitas perkawinan (Oshio dkk., 2013; Barstad, 2014; Britt \& Roy, 2014). Dengan ciri-ciri seperti itu maka pasangan ini disebut 
sebagai tipe fungsional. Pasangan ini tetap menjalankan fungsi-fungsi keluarga melalui pembagian peran yang adil dan seimbang.

Berbagi tugas rumah tangga antara suami istri berkorelasi positif dengan perasaan cinta dan suka (Ogolsky \& Bowers, 2013), kepuasan perkawinan (Taniguchi \& Kaufman, 2020) dan merupakan salah satu bentuk perilaku menjaga hubungan (Malinen dkk., 2012). Pembagian peran secara seimbang juga berkaitan dengan aktivitas seksual. Keterlibatan suami dalam pengasuhan anak maupun pekerjaan rumah tangga lainnya berhubungan dengan kepuasan terhadap kuantitas maupun kualitas hubungan seksual (Carlson dkk., 2016). Sebaliknya peran dan pekerjaan rumah tangga yang berlebihan dapat memprediksi rendahnya kepuasan seksual baik pada suami maupun istri (Maas dkk., 2015).

Pasangan tipe fungsional ini mungkin saja sedikit bermasalah pada konektivitas dengan komunikasi yang kurang intensif dan terbuka. Menurut Monk dkk. (2020), perbedaan dalam mengatasi konflik diantara pasangan berkaitan dengan kualitas perkawinan yang rendah. Meskipun tidak masuk dalam kategori yang rendah, namun penerimaan terhadap kekurangan pasangan relatif kurang optimal. Oleh karena itu, sebagaimana tampak dalam profil, tipe ini menunjukkan skor keharmonisan yang berada pada posisi paling rendah dari semua indikatornya. Hal tersebut berdampak pada konflik dengan pasangan yang terkadang muncul dan tidak terselesaikan, sehingga kebahagiaan yang dirasakan tidak optimal.

Tipe bertahan memiliki rerata skor di bawah rerata skor populasi. Dilihat dari profil garisnya, tipe fungsional menunjukkan satu garis zigzag atau tidak seimbang untuk indikator-indikatornya. Pasangan suami istri dengan tipe ini memiliki gairah dan sikap saling menghargai yang relatif rendah, dengan konektivitas dan sikap saling menerima yang relatif lebih tinggi.
Rerata skor kerjasama berupa berbagi peran dan tanggung jawab dalam menjalankan peran ada pada posisi di tengah antara rerata skor gairah dan saling menghargai dengan saling menerima dan keharmonisan. Sikap saling menghargai (menghormati) dan gairah sejajar dengan skor kebahagiaan yang rendah. Hormat merupakan kaidah yang memiliki peranan besar dalam mengatur interaksi dalam masyarakat Jawa (Magnis-Suseno, 2001), oleh karena itu kebahagiaan suami atau istri dapat dipengaruhi oleh sikap saling hormat diantara keduanya. Hasil penelitian terdahulu menunjukkan bahwa orang-orang yang puas dan berbahagia di dalam perkawinannya melaporkan adanya kasih sayang dan hormat dari pasangannya (Dew \& Wilcox, 2013).

Pasangan tipe bertahan memiliki skor kebahagiaan yang jauh lebih rendah dibandingkan skor keharmonisan. Hal ini mengandung makna bahwa pasangan ini relatif kurang berbahagia walaupun hubungannya rukun. Bagi orang Jawa, harmoni dalam hubungan sangat dihargai dan dijunjung tinggi (Roqib, 2007). Oleh karena itu orang Jawa cenderung selalu berusaha menghindari perselisihan, terutama perselisihan yang terang-terangan (Ahimsa-Putra, 2012). Pasangan ini nampaknya berusaha menghindari perselisihan untuk mempertahankan keharmonisan hubungan. Namun demikian, keharmonisan tersebut bisa jadi merupakan kondisi yang disebut oleh Lestari (2013) sebagai kerukunan semu, yaitu kondisi rukun yang hanya ada di permukaan. Beberapa permasalahan yang ada cenderung terpendam dan tidak terselesaikan. Oleh karena itu, meskipun tampak harmonis, pasangan ini tidak merasakan kebahagiaan.

Deskripsi tersebut menunjukkan bahwa pasangan dengan tipe bertahan merupakan pasangan yang menjaga keharmonisan rumah tangganya melalui pembagian peran dan tanggung jawab dalam rumah tangganya. Pasangan tipe ini merasa membutuhkan satu sama lain dan menjaga 
konektivitas melalui komunikasi yang terbuka. Namun di sisi lain, pasangan ini kurang dapat mempertahankan kehangatan hubungan yang ditunjukkan dengan minimnya gairah diantara suami istri serta rasa menghargai satu sama lain. Oleh karena itu, meskipun pasangan ini tampak rukun dan harmonis, namun tingkat kebahagiaannya relatif berada jauh di bawah rata-rata.

Tiga tipe kualitas perkawinan yang ditemukan menunjukkan perbedaan secara signifikan untuk semua indikatornya. Ketiganya memiliki dinamika yang berbeda. Meskipun demikian jika dilihat dari profilnya, maka perbedaan paling mencolok ada pada indikator gairah, saling menghargai, dan kebahagiaan. Hal ini sejalan dengan hasil penelitian sebelumnya menunjukkan bahwa pasangan suami istri bahagia yang saling support satu sama lain melaporkan bahwa mereka memiliki keintiman yang lebih tinggi (Rauer \& Volling, 2013).

Penelitian ini menemukan bahwa tidak ada perbedaan karakteristik dalam hal usia perkawinan, jumlah anak, tingkat pendidikan, pengeluaran keluarga tiap bulan, serta pekerjaan diantara ketiga tipe kualitas perkawinan. Hasil ini sejalan dengan penelitian Nurhayati (2017) yang menunjukkan bahwa tidak ada perbedaan kualitas perkawinan ditinjau dari beberapa aspek demografi seperti tingkat pendidikan, status sosial ekonomi, dan jenis pekerjaan. Penelitian Setiawati dan Nurhayati (2020) juga menunjukkan rendahnya kontribusi jumlah pengeluaran keluarga tiap bulan terhadap kualitas perkawinan.

Penelitian ini masih memiliki keterbatasan dari sisi jumlah responden. Selain itu, masih diperlukan validasi terhadap tipe kualitas perkawinan yang dihasilkan. Oleh karena itu, tindak lanjut yang dapat dilakukan terhadap penelitian ini adalah melakukan penelitian serupa dengan responden yang lebih banyak. Hal ini sekaligus bertujuan untuk memvalidasi tiga kualitas perkawinan yang sudah dihasilkan dalam penelitian ini.

\section{Simpulan}

Kualitas perkawinan orang Yogyakarta dapat dibedakan menjadi tiga tipe, yaitu tipe bahagia, tipe fungsional, dan tipe bertahan. Sebagian besar subjek penelitian ini masuk dalam tipe bahagia, yang merupakan tipe ideal dengan kualitas baik pada semua indikator. Sebaliknya tipe bertahan, dengan karakteristik adanya hubungan yang harmonis namun kurang bahagia merupakan tipe dengan kualitas terendah. Berdasarkan hasil penelitian ini juga dapat disimpulkan bahwa karakteristik demografi seperti usia perkawinan, tingkat pendidikan, jenis pekerjaan, maupun jumlah anak tidak memengaruhi terbentuknya tipe-tipe kualitas perkawinan.

\section{Daftar Pustaka}

Abreu-Afonso, J., Ramos, M. M., QueirozGarcia, I., \& Leal, I. (2021). How couple's relationship last over time? A model for marital satisfaction. Psychological Reports, O(0), 1-27. http://dx.doi.org/10.1177/00332941211 000651

Ahimsa-Putra, H. S. (2012). 'Baik' dan 'buruk' dalam budaya Jawa-Sketsa tafsir nilai-nilai budaya Jawa'. Balai Pelestarian Nilai Budaya.

Allen, W. D., \& Olson, D. H. (2001). Five types of African-American marriages. Journal of Marital and Family Therapy, 27(3), 301-314. https://doi.org/10.1111/j.17520606.2001.tb00326.x

Anderson, C. A., \& Sedikides, C. (1991). Thinking about people: Contributions of a typological alternative to associationistic and dimensional models of person perception. Journal of Personality and Social Psychology, 60(2), 203-217. https://doi.org/10.1037/00223514.60.2.203 
Arora, P. (2012). Typology of web 2.0 spheres: Understanding the cultural dimensions of social media spaces. Current Sociology, 60(5), 599-618. https://doi.org/10.1177/ 0011392112440439

Barstad, A. (2014). Equality is bliss? Relationship quality and the gender division of household labor. Journal of Family Issues, 35(7), 972-992. https://doi.org/10.1177/0192513X1452 2246

Bechter, B., Brandl, B., \& Meardi, G. (2012). Sectors or countries? Typologies and levels of analysis in comparative industrial relations. European Journal of Industrial Relations, 18(3), 185-202. https://doi.org/10.1177/095968011245 2691

Britt, S. L. \& Roy, R. R. N. (2014). Relationship quality among young couples from an economic and gender perspective. Journal of Family and Economic Issues, 35, 241-250. https://doi.org/10.1007/s10834-0139368-x

Carlson, D. L., Hanson, S., \& Fitzroy, A. (2016). The division of child care, sexual intimacy, and relationship quality in couples. Gender \& Society, 30(3), 442-466. https://doi.org/10.1177/089124321562 6709

Carr, D., Freedman, V. A., Cornman, J. C., Schwarz, N. (2014). Happy marriage, happy life? Marital quality and subjective well-being in later life. Journal of Marriage and Family, 76(5), 930-948.

https://doi.org/10.1111/jomf.12133

Chang, E. S. (2016). Kirogi women's psychological well-being: The relative contributions of marital quality, mother-child relationship quality, and youth's educational adjustment. Journal of Family Issues, 39(1), 209229.
https://doi.org/10.1177/0192513X1663 2265

Cohen, O., Geron, Y., \& Farchi, A. (2010). A typology of marital quality of enduring marriages in Israel. Journal of Family Issues, 31(6), 727-747. https://doi.org/10.1177/0192513X0935 8566

Collier, D., LaPorte, J., \& Seawright, J. (2012). Putting typologies to work: Concept formation, measurement, \& analytic rigor. Political Research Quarterly, 65(1), 217-232. https://doi.org/10.1177/106591291243 7162

Dew, J., \& Wilcox, W. B. (2013). Generosity and the maintenance of marital quality. Journal of Marriage and Family, 75(5), 1218-1228. https://doi.org/10.1111/jomf.12066

Dush, C. M. P., \& Taylor, M. G. (2012). Trajectories of marital conflict across the life course: Predictors and interactions with marital happiness trajectories. Journal of Family Issues, 33(3), 341-368. https://doi.org/10.1177/ 0192513X11409684

Goldfarb, M. R., \& Trudel, G. (2019). Marital quality and depression: A review. Marriage \& Family Review, 55(8), 737763. https://doi.org/ 10.1080/01494929 .2019 .1610136

Fowers, B. J., \& Owenz, M. B. (2010). A eudaimonic theory of marital quality. Journal of Family Theory and Review. 2 , 334-352. https://doi.org/10.1111/j.17562589.2010.00065.x

Heiman, J. R., Long, J. S., Smith, S. N., Fisher, W. A., Sand, M. S., \& Rosen, R. C. (2011). Sexual satisfaction and relationship happiness in midlife and older couples in five countries. Archives of Sexual Behavior, 40(4), 741-753. https://doi.org/10.1007/s10508-0109703-3 
Herawati, T., Kumalasari, B., Musthofa, \& Tyas, F. P. S., (2018). Dukungan sosial, interaksi keluarga, dan kualitas perkawinan pada keluarga suami istri bekerja. Jurnal Ilmu Keluarga dan Konsumen, $\quad 11(1), \quad 1-12$. http://dx.doi.org/10.24156/jikk.2018.1 1.1.1

Kim, E. (2012). Marital adjustment and depressive symptoms in Korean Americans. Issues in Mental Health Nursing, 33, 370-376. https://doi.org/ 10.3109/01612840.2012.656822

Kim, J. H., \& Ritchie, B. W. (2012). Motivation-based typology: An empirical study of golf tourists. Journal of Hospitality \& Tourism Research, 36(2), 251-280. https://doi.org/10.1177/109634801038 8661

Kim, S., Orpinas, P., Martin, R., Horne, A. M., Sullivan, T. N., \& Hall, D. B. (2010). A typology of behavioral adjustment in ethnically diverse middle school students. Journal of Psychoeducational Assessment, 28(6), 524-535. https://doi.org/ $10.1177 / 0734282909352801$

Lavee, Y., \& Olson, D. H. (1993). Seven types of marriage: Empirical typology based on ENRICH. Journal of Marital and Family Therapy, 19(4), 325-340. https://doi.org/10.1111/j.17520606.1993.tb00996.x

Lestari, S. (2013). Konsep dan transmisi nilai-nilai jujur, rukun, dan hormat (Disertasi tidak diterbitkan). Universitas Gadjah Mada, Fakultas Psikologi.

Liu, Y., \& Upenieks, L. (2020). Marital quality and well-being among older adults: A typology of supportive, aversive, indifferent, and ambivalent marriages. Research on Aging, October 2020.

https://doi.org/10.1177/016402752096 9149.
Maas, M. K., McDaniel, B. T., Feinberg, M. E., \& Jones, D. E. (2015). Division of labor and lultiple domains of sexual satisfaction among first-time parents. Journal of Family Issues, 39(1), 104127. https://doi.org/10.1177/0192513X1560 4343

Magnis-Suseno, F. (2001). Etika Jawa. Sebuah analisa falsafi tentang kebijaksanaan hidup Jawa. Gramedia Pustaka Utama.

Malinen, K., Tolvanen, A., \& Ronka, A. (2012). Accentuating the positive, eliminating the negative? Relationship maintenance as a predictor of twodimensional relationship quality. Family Relations, 61, 784-797. https://doi.org/10.1111/j.17413729.2012.00738.x

Malinen, K., Kinnunen, U., Tolvanen, A., Ronka, A., Wierda-Boer, H., \& Gerris, J. (2010). Happy spouses, happy parents? Family relationships among finnish and dutch dual earners. Journal of Marriage and Family, 72, 293-306. https://doi.org/10.1111/j.17413737.2010.00700.x

Mandara, J., \& Murray, C. B. (2002). Development of an empirical typology of African American family functioning. Journal of Family Psychology, 16(2), 318-337. https://doi.org/10.1037//08933200.16.3.318

Marini, C. M., Ermer, A. E., Fiori, K. L., Rauer, A. J., \& Proulx, C. M. (2020). Marital quality, loneliness, and depressive symptoms later in life: the moderating role of own and spousal functional limitations. Research in Human Development, 17(4), 211234. https://doi.org/10.1080/15427609. 2020.1837598

Meloy, J. R., Hoffmann, J., Guldimann, A., \& James, D. (2012). The role of warning behaviors in threat assessment: An exploration and suggested typology. Behavioral 
Sciences and the Law, 30, 256-279. https://doi.org/10.1002/bsl.999

Messina, R., Due-Christensen, M., KellerSenn, A., Polek, E., Fantini, M. P., \& Sturt, J. (2018). Couples living with type 1 diabetes: An integrative review of the impacts on health and wellbeing, Journal of Health Psychology, 26(3), 412-437.

https://doi.org/10.1177/135910531881 7356

Mills, C., \& Pawson, K. (2012). Integrating motivation, risk-taking and selfidentity: A typology of ICT enterprise development narratives. International Small Business Journal, 30(5), 586606.

https://doi.org/10.1177/026624261039 0594

Monk, J. K., Ogolsky, B. G., \& Rice, T. M. (2020). The role of family-of-origin environment and discrepancy in conflict behavior on newlywed marital quality. Journal of Social and Personal Relationships, 38(1), 124-147. https://doi.org/10.1177/026540752095 8473

Montesi, J. L., Fauber, R. L., Gordon, E. A., \& Heimberg, R. G. (2010). The specific importance of communicating about sex to couples' sexual and overall relationship satisfaction. Journal of Personal and Social Relationship, 28(5), 591-609. https://doi.org/10.1177/026540751038 6833

Mubarok, A. (2012). Nasehat perkawinan dan konsep hidup berkeluarga, Mubarok Institute.

Nuckolls, C. W., \& Krishnayya, M. V. (2010). Siblings and spouses in the context of culture. Journal of Family Theory \& Review, 2(4), 388-400. https://doi.org/10.1111/j.17562589.2010.00068.x

Nurhayati, S. R. (2017). Konsep, dinamika, dan pengukuran kualitas perkawinan orang Yogyakarta (Disertasi tidak diterbitkan). Universitas Gajah Mada, Fakultas Psikologi.

Ogolsky, B. G., \& Bowers, J. R. (2013). A meta-analytic review of relationship maintenance and its correlates. Journal of Social and Personal Relationships, 30(3), 343-367. https://doi.org/ $10.1177 / 026540751246333$

Olson, D. H., \& Fowers, B. J. (1993). Five types of marriage: An empirical typology based on ENRICH. The Family Journal, 1(3), 139-158. https://doi.org/10.1177/146144480605 9922

Oshio, T., Nozaki, K., \& Kobayashi, M. (2013). Division of household labor and marital satisfaction in China, Japan, and Korea. Journal of Family and Economic Issues, 34(2), 211-223. https://doi.org/10.1007/s10834-0129321-4

Purohit, Y. S., \& Simmers, C. A. (2010). The impact of dual-earner couples' beliefs about career priority on the support exchange well being relationship. Journal of Organizational Culture, Communication and Conflict, 14(1), 51-72.

Reis, H. T., \& Aron, A. (2008). Love: What is it, why does it matter, and how does it operate? Perspectives on Psychological Science, 3(1), 80-86. https://doi.org/10.1111/j.17456916.2008.00065.x

Roqib, M. (2007). Harmoni dalam budaya Jawa. Pustaka Pelajar.

Ruppanner, L., Branden, M., \& Turunen, J. (2018). Does unequal housework lead to divorce? Evidence from Sweden. Sociology, 52(1), 75-94, https://doi.org/10.1177/003803851667 4664

Setiawati, F. A., \& Nurhayati, S. R. (2020). Kualitas perkawinan orang Jawa: Tinjauan faktor jenis kelamin, usia perkawinan, jumlah anak, dan pengeluaran keluarga. Jurnal Ilmu Keluarga dan Konsumen, 13(1), 13-24. 
http://dx.doi.org/10.24156/jikk.2020.1 3.1.13

Stanley, S. M., Markman, H. J., \& Whitton, S. W. (2002). Communication, conflict, and commitment: Insight on the foundations on relationship success from a national survey. Family Process, 41(4), 659-675. https://doi.org/10.1111/j.15455300.2002.00659.x

Stidham, A. W., Draucker, C. B., Martsolf, D. S., \& Mullen, L. P. (2012). Altruism in survivors of sexual violence: The typology of helping others. Journal of the American Psychiatric Nurses Association, 18(3), 146-155. https://doi.org/10.1177/107839031244 0595

Stokes, J. E. (2017). Marital quality in later life: A dyadic analysis of older married couples in Ireland. Journal of Social and Personal Relationships, 34(1), 114-135.

https://doi.org/10.1177/016402751562 $\underline{4224}$

Taniguchi, H., \& Kaufman, G. (2020). Sharing the load: Housework, joint decision-making, and marital quality in Japan. Journal of Family Studies. https://doi.org/10.1080/13229400.2020 .1769707

Tolea, M. I., Terracciano, A., Milaneschi, Y., Metter, E. J., \& Feerucci, L. (2012). Personality typology in relation to muscle strength. International Journal of Behavioral Medicine, 19, 382-390.

https://doi.org/10.1007/s12529-0119166-5

Troxel, W. M., Braithwaite, S. R., Sandberg, J. G., \& Holt-Lunstad, J. (2017). Does improving marital quality improve sleep? Results from a marital therapy trial. Behavioral Sleep Medicine, 15(4), 330-

343. https://doi.org/10.1080/1540200 2.2015.1133420
Van der Vaart, L., Witte, H. D., Van den Broeck, A., \& Rothmann, S., (2017). A psychosocial typology of the unemployed in South Africa, South African Journal of Psychology, 48(2), 179-192. https://doi.org/10.1177/008124631772 1600 